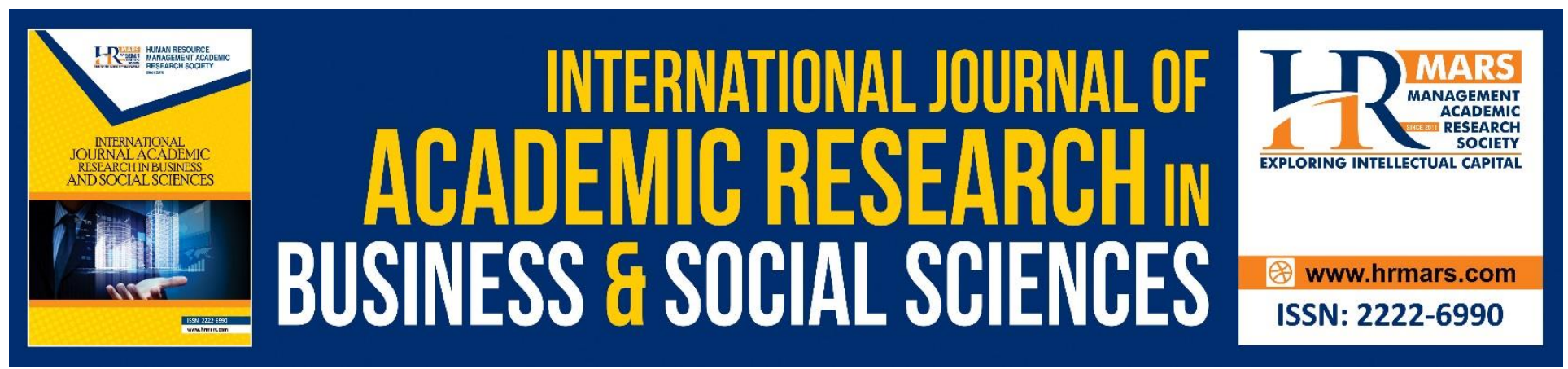

\title{
The Influence of Supervisor Support, Organizational Trust on Workplace Deviant Behavior: Do Psychological Contract Matter?
}

\begin{abstract}
Abdul Mutalib Mohamed Azim, Mohd Sufiean Hassan, Dina Syamilah Zaid, Mohd Afendi Daud
\end{abstract}

To Link this Article: http://dx.doi.org/10.6007/IJARBSS/v10-i2/6895

DOI:10.6007/IJARBSS/v10-i2/6895

Received: 25 December 2019, Revised: 12 January 2020, Accepted: 30 January 2020

Published Online: 13 February 2020

In-Text Citation: (Azim et al., 2020)

To Cite this Article: Azim, A. M. M., Hassan, M. S., Zaid, D. S., \& Daud, M. A. (2020). The Influence of Supervisor Support, Organizational Trust on Workplace Deviant Behavior: Do Psychological Contract Matter?

International Journal of Academic Research in Business and Social Sciences, 10(2), 116-132.

Copyright: (C) 2020 The Author(s)

Published by Human Resource Management Academic Research Society (www.hrmars.com)

This article is published under the Creative Commons Attribution (CC BY 4.0) license. Anyone may reproduce, distribute, translate and create derivative works of this article (for both commercial and non-commercial purposes), subject to full attribution to the original publication and authors. The full terms of this license may be seen at: http://creativecommons.org/licences/by/4.0/legalcode

Vol. 10, No. 2, 2020, Pg. 116 - 132

http://hrmars.com/index.php/pages/detail/IJARBSS

JOURNAL HOMEPAGE

Full Terms \& Conditions of access and use can be found at http://hrmars.com/index.php/pages/detail/publication-ethics 


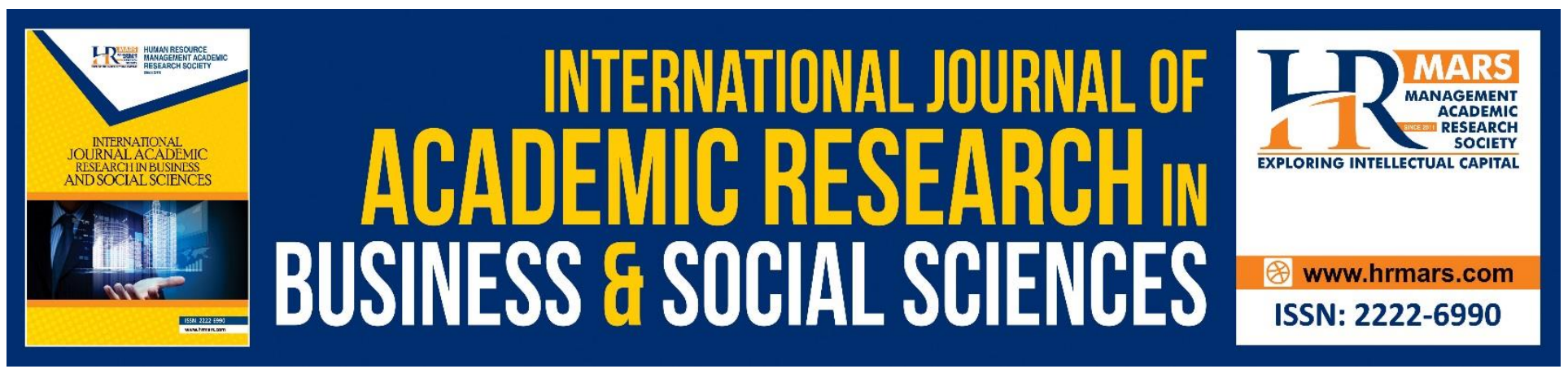

\title{
The Influence of Supervisor Support, Organizational Trust on Workplace Deviant Behavior: Do Psychological Contract Matter?
}

\author{
Abdul Mutalib Mohamed Azim, Mohd Sufiean Hassan, Dina \\ Syamilah Zaid, Mohd Afendi Daud \\ Kolej Universiti Islam Melaka (KUIM), Malaysia
}

\begin{abstract}
This study aims to determine the effect of psychological contracts as a mediator in the relationship between supervisor support, organizational trust and workplace deviant behaviour. For this purpose, a total of 350 lecturers in seven Private Higher Education Institutions (IPTS) around Selangor and Kuala Lumpur were selected as research respondents. The questionnaire was distributed to respondents using instruments taken from the original source. This study found that organizational trust influences workplace deviant behaviour, while supervisor support does not affect workplace deviant behaviour. The study also found that supervisory support and organizational trust influence psychological contracts and psychological contracts influence workplace deviant behaviour. Finally, for mediation analysis, psychological contracts significantly influence the relationship between supervisor support, organizational trust and workplace deviant behaviour at work. This study concludes that supervisory support and organizational trust increase psychological contracts and thus reduce the workplace deviant behaviour among lecturers.
\end{abstract}

Keywords: Psychological Contract, Supervisor Support, Organizational Trust, Workplace Deviant Behaviour

\section{Introduction}

Workplace deviant behaviour refers to "voluntary behaviour that violates significant organizational norms and thus threatens the well-being of an organization, its members, or both" (Robinson \& Bennett 1995, p. 556). This behaviour is associated with voluntary behaviour among employees who either lack the motivation to comply or are motivated to violate social norms (Bennett \& Marasi, 2015). Some frameworks of deviant behaviour in the workplace distinguish between behaviours directed at individuals and organizations and the structure of these two factors is empirically supported (e.g. Robinson \& Bennett 1995, Bennett \& Robinson 2000, Bennett \& Marasi, 2015). Causes or predictors of deviant behaviour in the workplace include personal factors and environmental factors. Although many factors influence individuals to engage in workplace deviant 
behaviour. However, research has also found that organizational support is one of the factors that can influence workplace deviant behaviour (Narayanan \& Murphy, 2017; Chen, Fah \& Jin, 2016).

Employees with supervisor support, such as getting proper feedback, fair treatment and adequate assistance in developing employee skills in achieving job goals will have a psychological impact (Eisenberger \& Stinglhamber, 2011). Likewise, employees' trust in the organization, a sense of confidence, the belief that the employer will support them in an honest manner (Gilbert \& Tang, 1998), fair in fulfilling the responsibility of caring for the welfare of the employee, is also seen as a factor that can affect the employees' psychologically. Both of these factors, namely supervisor support and perceived organizational trust, can have psychological implications. Employees who believe that the organization has fulfilled their responsibilities indicate that the employer has fulfilled the psychological contract. Psychological contracts refer to “employees' beliefs about reciprocal obligations between the employee and his or her organization, where these obligations are based on perceived promises and not necessarily recognized by agents of the organization" (Morrison \& Robinson, 1997, p. 229).

When employees believe that an organization has fulfilled their obligations such as supporting or fulfilling promises, it means that the psychological contract has been fulfilled, and as an exchange, the employee will exhibit good behaviour (Azim, Ahmad, Omar \& Silong, 2015). This is in line with the theory of psychological contract in which reciprocal relationships exist between employeesemployers who share a common interest (Morrison \& Robinson, 1997). However, if one party assumes that the other party fails to fulfil its obligations or promises, then it is a breach of the psychological contract. As a result, employees may find themselves being betrayed, this can cause employees to feel frustrated and angry (Eckerd, Hill, Boyer, Donohue \& Ward, 2013) and subsequently affect negative or deviant behaviour (Ahmed, Kiyani \& Hashmi, 2013). However, only a few empirical studies have been conducted from the perspective of psychological contract and workplace deviant behaviour (Li \& Chen, 2018).

Previous studies examining deviant behaviour among academician have also been lacking (e.g., Unal, 2012; Adeoti, Shamsudin \& Wan, 2017; Hanımoğlu, 2018). According to Unal (2012), 50 per cent of teachers practice deviancy in schools and this behaviour has affected the quality of teaching. In general, teaching is stressful work due to high workload, large class size, insufficient pay, and pressures for publication, role conflict, student deviance and low professional status (Hakanen, Bakker \& Schaufeli, 2006; Bakker, \& Demerouti, 2016). Although previous studies looked at the perspectives of school teachers, this study was conducted among private higher education institution lecturers. The cumulative effect of high demands on faculty work on the emotions, productivity and attitudes of faculty members negatively affects their relationships with colleagues and students. When this happens, the effect is on the behaviour of the lecturers which will lead to the negative behaviour. To prevent this from happening, support from the supervisor (in the context of this study is the head of the department) and believe that the organization or institution will help them cope with job demands. This study assumes that when a lecturer receives supervisor support and believes that the institution is helping them, their psychological contract is fulfilled, the effect is that deviant behaviour will decrease. This study aimed to determine the influence of psychological contract as mediator in influencing the relationship between supervisor supports, organizational trust in workplace deviant behaviour. 
INTERNATIONAL JOURNAL OF ACADEMIC RESEARCH IN BUSINESS AND SOCIAL SCIENCES

Vol. 10, No. 2, Feb, 2020, E-ISSN: 2222-6990 @ 2020 HRMARS

\section{Literature Review}

\section{Supervisor Support and Workplaces Deviant Behaviour}

Highly supportive supervisors can increase employee productivity, while less supportive supervisors are perceived as a hindrance to employee success (Anderson, 2006) and can increase deviance behaviour (Ahmad \& Omar, 2013). Inadequate supervisory support, therefore, may lead to staff deviance, which in turn can negatively impact an organization's performance (Menguc et al., 2013). In this regard, social exchange theory shows that greater support from supervisors can help employees be more responsible and that they respond to the organization; for example, with supervisor support, employees can perform their tasks better and thus achieve organizational goals. On the contrary, when employees receive less support from their supervisors, employees will not put maximum efforts on their job (Dysvik et al., 2014). Studies by Khan, Mahmood, Kanwal and Latif (2015) also confirm that supervisor support reduces workplace deviant behaviour. Employees are found to have a greater tendency to engage in unproductive behaviours, but deviance behaviours will decrease if employees receive supervisor support (Pandey, Schulz \& Camp, 2018; Zulfadhli, 2018). $\mathrm{H1}$ : Supervisor support significantly influences workplace deviant behaviour.

\section{Organization Trust and Workplaces Deviant Behaviour}

Organization trust refers to the employee's trust and belief towards origination that fostering relationships employer-employees in the organization (Alias et al., 2013). Lack of trust is associated with a variety of implications, including declining productivity, inefficiencies, profit reductions, and antisocial behaviour (Thau et al., 2007). Organization trust is found to be the determinant of employees' intentions and behaviours in the workplace (Ozyilmaz, 2010). Previous studies have found that organizations provide support to employees such as training or rewards, or by appreciating individual contributions and helping them to develop; employees are able to help organizations achieve their vision and mission (Liao et al., 2004; Wayne, Shore, Bommer \& Tetrick 2002). Lack of organizational trust as a result of organizational actions that fail to meet the promises or responsibilities that the organization should provide, may result in negative behaviours such as workplace deviant behaviour (Aquino \& Bayron, 2002; Yin, Yusof, Lok \& Zakariya, 2018). Thau et al. (2007) showed that there is a negative relationship between organizational trust and workplace deviant behaviour. Akhigbe and Sunday (2018) also found that the organizational trust has a negative impact towards workplace deviant behaviour. It is seen that the organization trust is a factor that will mitigate employee engage in workplace deviant behaviour.

$\mathrm{H}$ 2: Organizational trust significantly influence workplace deviant behaviour

\section{Supervisor Support and Psychological Contract}

The relationship between supervisor support and psychological contract can be explained through social exchange theory. Employees will feel that their organization is committed to them when they feel that their well-being is being cared for and respected by the organization. This will create a sense of obligation in which the employee will be committed to his or her organization (Azim, Ahmad, Omar \& Silong, 2012; Azim et al., 2015). Eisenberger, Armeli, Rexwinkel, Lynch and Rhoades (2001) found that supervisor support would strengthen individual affective ties to their organization and create a sense of loyalty to the organization. This is because there is an element of belief that the organization is concerned about the employees' wellbeing (Eisenberger \& Stinglhamber, 2011). Guchait, Cho and 
INTERNATIONAL JOURNAL OF ACADEMIC RESEARCH IN BUSINESS AND SOCIAL SCIENCES Vol. 10, No. 2, Feb, 2020, E-ISSN: 2222-6990 @ 2020 HRMARS

Meur (2015) indicates that supervisor support enhances employees' perceptions of organizational support, which in turn builds on the belief that the organization has fulfilled its responsibilities in fulfilling employee psychological contracts. Similarly, Karabey and Yildirim (2016) found that supervisor support influence employee psychological contracts.

H3: Supervisor support significantly affects psychological contract

\section{Organizational Trust and Psychological Contract}

Previous studies have done little to examine the impact of organizational trust on psychological contracts directly. A study by Cheung, Wong and Yuan (2017) found that psychological contracts mediates relationship between organizational trust and contextual performance. Meanwhile, Liu, Huang, Huang and Chen. (2013) studied the relationship between psychological contract breach, organizational trust, and organizational citizenship behavior in the hotel industry. Their study found that psychological contracts breach negatively and significantly affected organizational trust and organizational citizenship behavior. Golparvar, Kamkar and Javadian (2012) studied the relationship between organizational trust and psychological contract among employees of an industrial organization in Esfahan, Iran, and found that the organization trust influence psychological contract. Similarly, a study conducted on 220 non-executive employees working in the Department of Agriculture Malaysia revealed that there is a significant relationship between organization trust and psychological contract (Sani, David \& Ismail, 2018).

H4: Organizational trust significantly affects psychological contracts

\section{Psychological Contract and Workplace Deviant Behaviour}

According to social exchange theory (Blau, 1964), employees may respond to psychological contracts breach with negative work attitudes, and this may make employees more likely to engage in workplace deviant behaviour (Law \& Zhou, 2014), such as absenteeism ( Daouk-Öyry Anouze, Otaki, Dumit \& Osman 2014), and behaviours that violate organizational rules (Bordia, Restubog \& Tang, 2008). In addition, previous studies have confirmed that unfulfilled psychological contracts can trigger absenteeism (Deery, Iverson \& Walsh, 2006) and anti-citizenship behaviour (Kickul, 2001). Based on the analysis of 300 doctors and nurses in Pakistan, Ahmed et al., (2013) found that psychological contracts breach had a positive direct effect on doctor and nurse workplace deviant behaviour. When psychological contracts are not fulfilled, employees may become angry and frustrated (Eckerd et al., 2013). These negative emotions can induce workplace deviant behaviour (Fox \& Spector, 2002; Penney \& Spector, 2005). In addition, unfulfilled psychological contracts mean that employees see a conflict between what the organization promises and what they receive. Conway, Guest and Trenberth (2011) also show that violations of psychological contracts related to employees' emotional well-being, and it can significantly influence workplace deviant behaviour. Therefore, to eliminate the imbalance, they try to reduce the effort. Ultimately, this leads to workplace deviant behaviour (Mount, Ilies \& Johnson, 2006; Jensen \& Ryan, 2010; Li, \& Chen, 2018). H5: Psychological contracts significantly influence workplace deviant behaviour 
INTERNATIONAL JOURNAL OF ACADEMIC RESEARCH IN BUSINESS AND SOCIAL SCIENCES Vol. 10, No. 2, Feb, 2020, E-ISSN: 2222-6990 @ 2020 HRMARS

\section{Psychological Contracts as a mediator in the Relationship between Supervisor Support and Workplace Deviant behaviour}

Previous studies show that one of the organizational factor that has the potential contribute to workplace deviant behaviour is supervisor support (Dysvik et al., 2014; Huang, Wang, Shi \& Xie, 2015; Pandey, Schulz \& Camp, 2018). In general, past studies found that supervisor support has a negative impact towards workplace deviant behaviour. This means that low supervisor support increases the involvement of employees in the workplace deviant behaviour. Previous studies have also found that supervisor support influences psychological contracts (Menguc et al., 2013; Khan et al., 2015), and fulfilling workers' psychological contracts will shape good employee behaviour and reduce workplace deviant behaviour (Ahmed et al., 2013). This means that supervisor support, such as assisting employees in fulfilling organizational promises (for example, career development), mean that the organization has fulfilled employees' psychological contracts, in return for such support, employees exhibit positive behaviour and indirectly reduce workplace deviant behaviour. Based on these arguments, this study builds on the following hypothesis:

H6: Psychological contract as mediator in explaining the influence of supervisor support on workplace deviant behaviour

\section{Psychological Contracts as a mediator in the Relationship between Organization Trust and Workplace Deviant behaviour}

Organizational trust is defined as the employees feeling of confidence towards employer and the belief that the employer will be honest (Gilbert \& Tang, 1998). Organizational trust can be created when the highest management actions are predictable and when leaders are consistent in their words and actions (Reina \& Reina, 1999). Based on the definition of organizational trust, it can be concluded that to increase organizational trust, two elements must be involved. That is, personal and professional beliefs, are psychological ideas that have the capacity to control individual behavior and intentions (Webster \& Wong, 2008; Samadi, Wei, Seyfee \& Yusoff, 2015). Organizational trust is the employee who believes that the organization executes its commitment to assist employees either in the form of job support or personal support. It is through this belief that the employee believes that the organization has fulfilled its psychological contract (Atkinson, 2007). Employees who believe their psychological contract has been fulfilled by the organization, of course, feel happy at work; this will indirectly reduce their workplace deviant behaviour (Mount et al., 2006; Jensen \& Ryan, 2010; Li \& Chen, 2018). The following hypothesis of the study was constructed:

H7: Psychological contracts as mediators to explain the influence of organizational trust on workplace deviant behaviour

\section{Methodology}

The study respondents consisted of lecturers at seven Higher Learning Institutions around Klang Valley, Malaysia. The questionnaire was distributed to 420 respondents randomly, of which 41 questionnaires were found incomplete and 29 were not returned. In total, we obtained 350 valid responses to the procedure analysis data. The instruments used to measure latent construction in this study have been adapted from previous studies and re-examined to fit the specific circumstances of the current study. To measure supervisor support, three items adopted from the original instrument by Palomo, Beinart and Cooper (2010) were used. To measure organizational trust, five 
items developed by Robinson (1996) were used for this study. Then the measurement of psychological contracts using five items was developed by Robinson and Morrison (2000), based on a five-point Likert scale ranging from 1 (Never) to 5 (Very often). Finally, Workplace deviance behaviour is measured using 7 items developed by Peterson (2002). Interpersonal workplace deviant behaviour has been defined as voluntary behaviour directed at or targeted at organizational members. Examples of items include "Saying something that hurts someone at work", "insulting someone at work", "Being rude to someone at work" and "Embarrassing someone in a public place at work". The questionnaire required respondents to rate on a five-point Likert scale from 1 (strongly disagree) to 5 (strongly agree). However, this study used only four items as three items were dropped because the factor load was less than 0.7 . In the following section, we report the results of model measurements that determine the relationship between latent constructs and dependent variables, including the reliability and validity of measurements and model structures that determine relationships between variables.

\section{Results}

Confirmatory Factor Analysis (CFA) is used to describe the nature of the relationship between latent variables, and the manifest variables that measure latent variables. The models presented in this study consist of one mediation variable namely psychological contract, and two latent variables: supervisor support and organizational trust, as well as one dependent variable that is workplace deviant behaviour.

Table 1 reports the mean, and the factor loadings of all variables. All factors load are greater than 0.7 , which provides evidence that supports convergent validity for all indicators (Anderson \& Gerbing 1988). The reliability of the construction indicators is shown in Table 1. All Cronbach's alpha coefficients exceed the acceptable threshold level of 0.7 (Nunally \& Bernstein, 1994). This finding concludes that the test results generally support the constructs reliability and indicators. Furthermore, convergent validity and discriminant validity of the measurement model were tested (Henseler et al., 2015; Hair et al., 2010; Fornell \& Larcker, 1981). First, convergence validity is assessed by assessing the factor loadings and composite reliability (CR) and Average Variance Extracted (AVE). As shown in Table 1, all factors load are greater than the specified criteria of 0.7. In addition, all CR values and AVE values were higher than the 0.7 and 0.5 , respectively. Therefore, this study concludes that the measurement model has sufficient convergent validity. 
INTERNATIONAL JOURNAL OF ACADEMIC RESEARCH IN BUSINESS AND SOCIAL SCIENCES

Vol. 10, No. 2, Feb, 2020, E-ISSN: 2222-6990 @ 2020 HRMARS

TABLE 1. Reliability and Convergence Validity for Measurement Models

\begin{tabular}{llllll}
\hline Construct & Mean & Factor Loading & $\begin{array}{l}\text { Cronbach's } \\
\text { alpha }\end{array}$ & CR & AVE \\
\hline Supervisor Support & 3.13 & 0.757 & 0.712 & 0.836 & 0.630 \\
SS1 & 3.73 & 0.832 & & & \\
SS2 & 3.37 & 0.791 & & & \\
SS3 & & & 0.863 & 0.902 & 0.648 \\
Organization Trust & 3.80 & 0.773 & & & \\
OT1 & 3.70 & 0.864 & & & \\
OT2 & 3.68 & 0.818 & & & \\
OT3 & 3.67 & 0.844 & & & \\
OT4 & 3.45 & 0.718 & & & \\
OT5 & & & 0.838 & 0.885 & 0.606 \\
Psychological Contract & 3.83 & 0.756 & & & \\
PC1 & 3.99 & 0.849 & & & \\
PC2 & 3.73 & 0.753 & & & \\
PC3 & 4.04 & 0.768 & & & \\
PC4 & 3.99 & 0.763 & & & \\
PC5 & & & 0.836 & 0.890 & 0.67 \\
Workplace Deviant Behavior & 2.69 & 0.786 & & & \\
WDB1 & 2.83 & 0.835 & & & \\
WDB4 & 2.84 & 0.836 & & & \\
WDB5 & 2.01 & 0.816 & & & \\
WDB6 & & & & & \\
\hline
\end{tabular}

To assess the discriminant validity, Table 2 reports the results of the Heterotrait-Monotrait (HTMT) analysis. Henseler, Ringle and Sarstedt (2015) proposed an alternative approach using simulation studies because the Fornell-Larcker method could not detect the lack of discriminant validity in normal research situations. It assesses the average correlation between indicators across constructs as compared to the average correlation between indicators within the same construct (see Henseler et al. (2015) for a detailed explanation of the HTMT criteria for assessing discriminant validity in structural equation modeling based on variance). The HTML values in Table 2 explain the estimated correlation between constructs. This study uses HTMT in SmartPLS to calculate the HTMT matrix.

TABLE 2. Heterotite-Monotrait (HTMT) Matrix

\begin{tabular}{lllll}
\hline Construct & $\begin{array}{l}\text { Psychological } \\
\text { Contract }\end{array}$ & $\begin{array}{l}\text { Organization } \\
\text { Trust }\end{array}$ & $\begin{array}{l}\text { Supervisor } \\
\text { Support }\end{array}$ & $\begin{array}{l}\text { Workplace } \\
\text { Deviant } \\
\text { Behavior }\end{array}$ \\
\hline $\begin{array}{l}\text { Psychological Contract } \\
\text { Organization Trust }\end{array}$ & 0.464 & & & \\
$\begin{array}{l}\text { Supervisor Support } \\
\text { Workplace Deviant Behavior }\end{array}$ & 0.386 & 0.292 & & \\
\hline
\end{tabular}


INTERNATIONAL JOURNAL OF ACADEMIC RESEARCH IN BUSINESS AND SOCIAL SCIENCES Vol. 10, No. 2, Feb, 2020, E-ISSN: 2222-6990 @ 2020 HRMARS

As described in Table 2, the discriminant validity among the study constructs was below the set value of 0.90 . If the HTMT value is 0.90 or greater than 0.90 (Gold, Malhotra \& Segars, 2001), this value indicates the existence of a validity problem. All values obtained were below the HTMT level of 0.90 (Gold et al., 2001) and this indicates that all construct are different or not the same or similar construct. As reported in Table 2, correlations between latent constructs are acceptable, indicating that there are no collinearity between variables.

\section{Model}

Based on Table 3, it was found that only one of the two independent constructs influenced workplace deviant behavior, namely, organizational trust $(\beta=-0.177, p=0.001)$, while supervisor support did not show a significant influence on workplace deviant behavior $(\beta=-0.083, p=0.095)$. Figure 1 shows the mediation construct in which psychological contracts show significant influence on workplace deviant behavior $(\beta=-0.355, p=0.000)$. Determination coefficient $\left(R^{2}\right)$ is equal to 0.24 , indicates that $24 \%$ of variation in workplace deviant behavior can be explained by all independent and mediation constructs.

TABLE 3. Summary of Coefficient Results Pathway on Workplace Deviant Behavior

\begin{tabular}{lllll}
\hline Construct & $\begin{array}{l}\text { Path } \\
\text { Coefficient }\end{array}$ & Statistic t & $p$ & Results \\
\hline Psychological Contract & -0.355 & 5.445 & 0.000 & Support \\
Supervisor Support & -0.083 & 1.672 & 0.095 & Not Support \\
Organization Trust & -0.177 & 3.431 & 0.001 & Support \\
\hline
\end{tabular}

Note: * The coefficient is significant at the $95 \%$ confidence level if the t statistics $>1.96(p<.05)$

Table 4 shows the analysis results of psychological contracts as a mediation in relationship between supervisor support, organizational trust and workplace deviant behaviour. The findings show that psychological contract fully mediate the relationship between supervisor's support and workplace deviant behaviour, since the direct relationship between supervisor support and workplace deviant behaviour has no significant relationship $(\beta=-0.083, p>0.05)$, while the supervisor support coefficient path to psychological contract was significant $(\beta=0.218, t=3.275, p<0.05)$ and psychological contract to workplace deviant behaviour $(\beta=-0.335, p<0.05)$ was also significant.

Whereas for the mediation analysis of psychological contracts in the relationship between organizational trust, and workplace deviant behaviour, the findings indicate that psychological contract is a partial mediate in the relationship between organizational trust and workplace deviant behaviour, since the direct relationship between organizational trust and workplace deviant behaviour still significant relationship $(\beta=-0.177, p<0.05)$, while the coefficient path of the organization's trust towards psychological contract was also significant $(\beta=0.351, t=4.012 ; p<0.05)$ and psychological contract to workplace deviant behaviour $(\beta=-0.335, p<0.05)$ is also significant . 
INTERNATIONAL JOURNAL OF ACADEMIC RESEARCH IN BUSINESS AND SOCIAL SCIENCES Vol. 10, No. 2, Feb, 2020, E-ISSN: 2222-6990 @ 2020 HRMARS

TABLE 4. Mediation Analysis Test Results

\begin{tabular}{lllllll}
\hline Indirect effect & & & $\begin{array}{l}\text { Coefficient path } \\
\text { Indirect Effect }\end{array}$ & $\begin{array}{l}\text { Statistic } \\
\mathrm{t}\end{array}$ & Significant \\
\hline Path & $\begin{array}{l}\text { Coefficient } \\
\text { path }\end{array}$ & Path & $\begin{array}{l}\text { Coefficient } \\
\text { path }\end{array}$ & & & \\
\hline SS $\rightarrow$ PC & 0.218 & PC $\rightarrow$ WDB & -0.355 & -0.077 & $3.275^{* *}$ & 0.000 \\
OT $\rightarrow$ PC & 0.351 & PC $\rightarrow$ WDB & -0.355 & -0.125 & $4.012^{* *}$ & 0.008 \\
\hline
\end{tabular}

SS= Supervisor Support; OT= Organization Trust; PC= Psychological Contract; WDB= Workplace Deviant Behavior

The structural model tested in this study indicates that supervisor support does not directly influence workplace deviant behaviour, but rather, organization trust directly influences workplace deviant behaviour. For mediation analysis, supervisor support and organizations trust influence psychological contracts significantly. Finally, psychological contracts significantly influence workplace deviant behaviour.

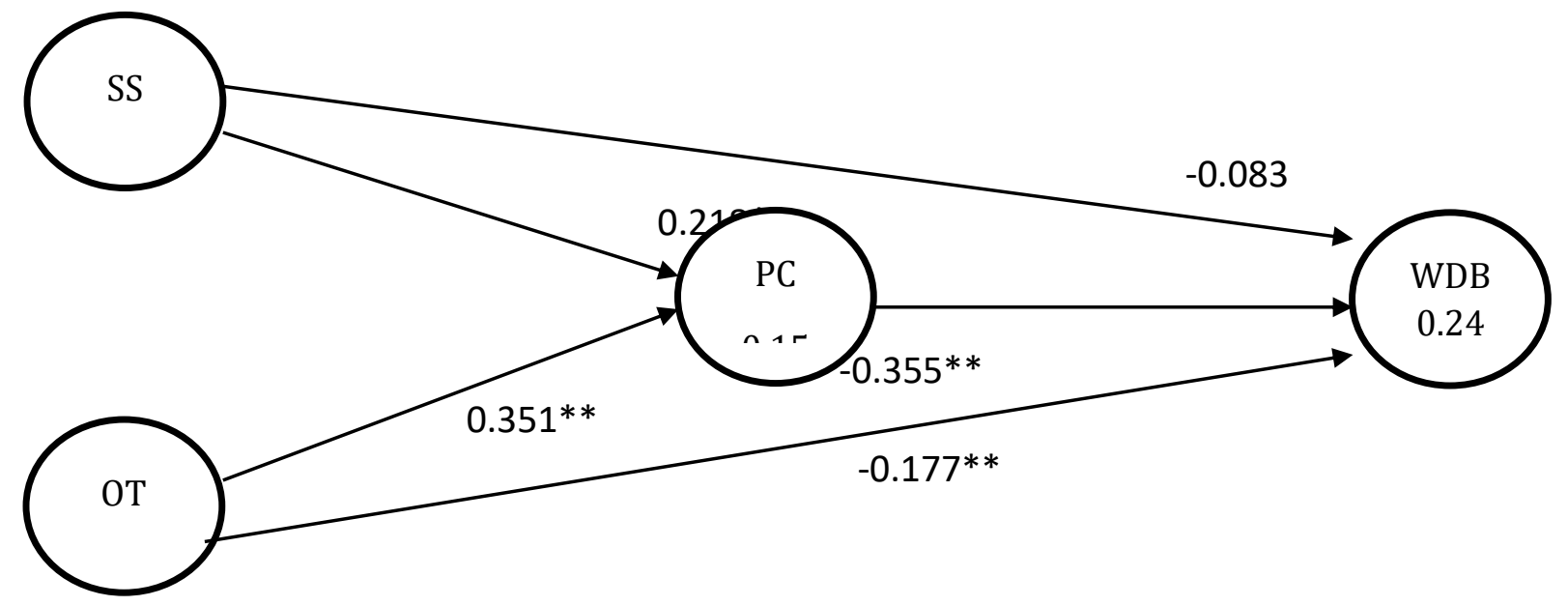

Figure 1. Psychology Contract as Mediation Contract

SS= Supervisor Support; OT= Organization Trust; $P C=$ Psychological Contract; WDB $=$ Workplace Deviant Behavior

\section{Discussion}

The findings show that supervisor support does not significantly influence workplace deviant behaviour. The findings of this study conclude that supervisor support is not essential in shaping lecturers' behaviour in the workplace. This study is contrary to previous studies which found that supervisor support mitigate workplace deviant behaviour (Menguc et al., 2013; Dysvik et al., 2014; Pandey et al., 2018). This may be due to the autonomous work environment of the lecturer without being subjected to strict supervision. This makes the supervisory role in the lecturer context less important because the lecturer performs the task less requiring the support of the supervisor.

Subsequent findings of this study indicate that organizational trust influences the workplace deviant behaviour. This indicates that the higher the lecturers trust their organization, the less 
INTERNATIONAL JOURNAL OF ACADEMIC RESEARCH IN BUSINESS AND SOCIAL SCIENCES Vol. 10, No. 2, Feb, 2020, E-ISSN: 2222-6990 @ 2020 HRMARS

workplace deviant behaviour will be. Lecturers who believe that institutions are honest and consistent in their words and actions, such as in term of reward distributive or career advancement, will shape their behaviour. This means that the higher the lecturer's trust in the institution, the more it will enhance the positive perception which in turn promotes positive behaviour and reduces workplace deviant behaviour. The results of this study support the second hypothesis and support the findings of a previous study by Akhigbe and Sunday (2018) which found that the organizational trust as a predictor to workplace deviant behaviour.

This study found that supervisor support had a significant positive influence on psychological contract. Supervisor support is an employee who receives constructive support and recognition from their supervisor. This study concludes that when employees feel that their organization is caring (supporting supervision and caring about employee well-being), this builds on the perception that the organization has fulfilled their promises (ie, fulfills psychological contracts). In other words, supervisor support is a form of support that always provides encouragement and guidance for employees to succeed. In the context of this study, the first hypothesis of the study is not supportive because the autonomy of lecturers' work requires less supervisor support, but rather in matters related to administrative processes such as institutional regulation requiring supervisor roles. Supervisor as an organizational agent in communicating institutional policies and regulations. In this study, the head of the department acts as an agent of institutional to deliver or communicate the policies and regulations. Supervisors' play their role in delivering the policy or regulation promised by the institution is crucial to the formation of the psychological contract. The results of this study support the findings of the study by Karabey and Yildirim, (2016) who indicated that supervisor support builds employee psychological contracts.

The results show that organizational trust significantly influence psychological contract. Organizational trust is where employees believe that the organization does not betray them and always shows a commitment to helping employees. This belief can create a positive emotion that the organization has fulfilled the promises it has made. The results of this study support the hypothesis that organizational trust significantly influence psychological contract. This means that the higher the trust of the academic staff towards organization, the higher the psychological contract will be. The results of this study are in line with the findings of Golparvar et al. (2012) who found that organization trust influenced psychological contracts.

The psychological contract in this study is an implicit contract between employees and their organization that is specific to what each one expects from each other to give and receive in a working relationship. The findings of this study indicate that there is a significant influence on psychological contract and workplace deviant behaviour. This means that the higher the psychological contract is, where the employee believes his or her organization has fulfilled what it has promised, the less workplace deviant behaviour. However, if the promises made by the organization are not fulfilled, the employee may feel frustrated and angry, the employee may respond with negative behaviour. This study is in line with the study by Conway et al. (2011) who found that psychological contract breach was influenced emotional well-being that could lead to workplace deviant behaviour.

The findings of the study indicate that psychological contracting is a full mediator because the direct relationship between supervisor support and workplace deviant behaviour is insignificant after the psychological contract is included in the mediation model. This means that psychological contract is an important factor in reducing workplace deviant behaviour. Academic staff felt that supervisors, 
INTERNATIONAL JOURNAL OF ACADEMIC RESEARCH IN BUSINESS AND SOCIAL SCIENCES Vol. 10, No. 2, Feb, 2020, E-ISSN: 2222-6990 @ 2020 HRMARS

if in the context of the higher education institute, the head of department at each faculty executed their responsibility such deliver all institution policy fairly, would increase the perception that supervisor as an agent of the organization had fulfilled organization promises, thus increasing the psychological contract which further reduced workplace deviant behaviour.

Finally, the findings show that psychological contracts are partial mediators, as the direct relationship between organizational trust and workplace deviant behaviour is still significant even when beta values decline after psychological contracts are included in the mediation model. Academic staff who believe that their organization is committed to providing support will increase the perception that the organization has fulfilled the responsibilities and promises it has made, and it also enhances the belief that the organization has fulfilled its psychological contract, which in turn creates positive emotions and mitigate workplace deviant behaviour.

\section{Conclusion}

This study contributes to the psychological contracts literature, as a mediator in explaining the relationship between supervisor support, organizational trust and workplace deviant behaviour. On the contrary, we are not aware of any study that theoretically explains and empirically explores the role of psychological contracts as mediators in the relationship between supervisor support, organizational trust and workplace deviant behaviour. In addition, most studies on psychological contracts do not explore the role of psychological contracts as mediators in explaining the workplace deviant behaviour. Although there are studies that study psychology contracts as mediator (e.g., Zagenczyk, Restubog, Kiewitz, Kiazad \& Tang, 2014) but they study transactional psychological contracts, while other studies are dominated by psychological contract violations/breach (which is how the employee reacts when the organization fails to meet the employee's psychological contract, Morrison \& Robinson, 1997; Rousseau, 2001; Fayyazi \& Aslani, 2015; Kaul \& Kaul, 2017; Griep, Vantilborgh \& Jones, 2018). Other studies also do not identify the role of psychological contracts as mediators, instead they study psychological contracts as direct predictors to workplace deviant behaviour (e.g., Fayyazi, \& Aslani, 2015; Li \& Chen, 2018; Malik, Bakri, Ajmal \& Malik, 2019).

This study also has practical implications for management practices. First and foremost, supervisors should be concern about their employees' expectations. Supervisors as organizational agents play an important role in implementing organizational rules and policies. The failure of the supervisor to carry out what the organization has promised can cause the employee less likely to trust the organization. This means that employees feel that their organization has breached the promises. As a result, employees may become angry and show their anger through workplace deviant behavior such as absenteeism or taking longer breaks, which will surely affect the organization productivity. Second, the implication of a policy is that the organization needs to ensure that what is set out in the policy needs to be implemented if the organization fails to implement the policy (promises made by the organization), it will cause employees disputing the organization and this can also have serious implications on employee behaviour.

The findings of this study prove that psychological contracts are important for the formation of employees' behaviours, especially in reducing workplace deviant behaviour. Workplace deviant behaviour can have a huge impact on an organization and can affect the productivity, reputation and 
INTERNATIONAL JOURNAL OF ACADEMIC RESEARCH IN BUSINESS AND SOCIAL SCIENCES Vol. 10, No. 2, Feb, 2020, E-ISSN: 2222-6990 @ 2020 HRMARS

profitability of the organization. In the context of higher education institutions, it is becoming more complicated as it involves the development of human capital. The results of this study show that supervisor support and organizational trust are crucial in meeting the demands of psychological contracts, which in turn can mitigate lecturers' workplace deviant behaviour. The reduction of workplace deviant behaviour in the workplace will certainly have a positive impact not only on the members of the institution but also on the overall performance of the institution.

\section{Corresponding Author}

Abdul Mutalib Mohamed Azim is a lecturer at Faculty of Hospitality Management, Kolej Universiti Islam Melaka (KUIM), Malaysia.

Email: mutalib.azim@kuim.edu.my.

\section{References}

Adeoti, M. O., Shamsudin, F. M., \& Wan, C. Y. (2017). Workload, work pressure and interpersonal deviance in academia: The mediating role of neutralization, international. Journal of Human Resource Studies 7(4): 1-22.

Ahmad, A., \& Omar, Z., (2013). Abusive Supervision and Deviant Workplace Behavior: The Mediating Role of Work-Family Conflict. The Journal of Human Resource and Adult Learning 9(2): 124130.

Ahmed, W., Kiyani, A. A., \& Hashmi, S. H. (2013). The study on organizational cynicism, organizational injustice and breach of psychological contract as the determinants of deviant work behavior. Act. Problems Economy 2: 145-154.

Akhigbe, O. J., \& Sunday, P. I. (2018). Organizational Trust and Workplace Deviant Behavior in Higher Institutions in Rivers State. International Journal of Managerial Studies and Research (IJMSR) 5(10): 48-62.

Alias, M., Mohd Rasdi, R., Ismail, M., \& Abu Samah, B. (2013). Predictors of workplace deviant behavior: HRD agenda for Malaysian support personnel. European Journal of Training and Development 37(2): 161-182.

Anderson, J. R. (2006). Managing Employees in the Service Sector: A Literature Review and Conceptual Development. Journal of Business and Psychology 20(4): 501-523.

Anderson, C. J., \& Gerbing, D. (1988). Structural equation modeling in practice: A review of recommended two-step approach. Psychological Bulletin 103: 411-423.

Aquino, K., \& Bayron, K. (2002). Dominating interpersonal behavior and perceived victimization in groups: evidence for a curvilinear relationship. Journal of Management 28(1): 69-87.

Atkinson, C. (2007). Trust and the psychological contract. Employee Relations 29(3): 227-246.

Azim, A. M. M., Ahmad, A., Omar, Z., \& Silong, A. D. (2012). Work-family psychological contract, job autonomy and organizational commitment. American Journal of Applied Sciences, 9(5), 740747.

Azim, A. M. M., Ahmad, A., Omar, Z., \& Silong, A. D. (2015). Does Psychological Contract on Workfamily Benefits Improve Employee Commitment? Asian Social Science, 11(13), 71-85

Bakker, A. B., \& Demerouti, E. (2016). Job demands-resources theory: Taking stock and looking forward. In Peter Y. Chen and Cary L. Cooper (Eds.). Work and wellbeing: a complete reference guide, Volume III. John Wiley \& Sons, Inc. 
INTERNATIONAL JOURNAL OF ACADEMIC RESEARCH IN BUSINESS AND SOCIAL SCIENCES

Vol. 10, No. 2, Feb, 2020, E-ISSN: 2222-6990 @ 2020 HRMARS

Bennett, R., \& Marasi, S., (2015). Workplace Deviance. In: James D. Wright (editor-in-chief): International Encyclopedia of the Social \& Behavioral Sciences, 2nd edition, 25. Oxford: Elsevier. pp. 722-726.

Bennett, R. J., \& Robinson, S. L. (2000). Development of a measure of workplace deviance. Journal of Applied Psychology 85: 349-360.

Blau, P. M. 1964. Exchange and power in social life. New York: John Wiley \& Sons.

Bordia, P., Restubog, S. L. D., \& Tang, R. L. (2008). When employees strike back: investigating mediating mechanisms between psychological contract breach and workplace deviance. Journal of Applied Psychology 93: 1104-1117.

Chen, L. L., Fah, B. C. U., \& Jin, T. H. (2016). Perceived Organizational Support and Workplace Deviance in the Voluntary Sector. 7th International Economics \& Business Management Conference, 5th \& 6th October 2015. Procedia Economics and Finance 35: 468-475

Cheung, M. F., Wong, C., \& Yuan, G. Y. (2017). Why mutual trust leads to highest performance: the mediating role of psychological contract fulfillment. Asia Pacific Journal of Human Resources 55(4): 430-453.

Conway, N., Guest, D.E. \& Trenberth, L. (2011). Testing the differential effects of changes in psychological contract breach and fulfilment. Journal of Vocational Behavior 79(1): 267-276.

Daouk-Öyry, L., Anouze, A. L., Otaki, F., Dumit, N. Y., \& Osman, I. (2014). The JOINT model of nurse absenteeism and turnover: a systematic review. International Journal Nursing Studies 51: 93110.

Deery, S. J., Iverson, R. D., \& Walsh, J. T. (2006). Toward a better understanding of psychological contract breach: a study of customer service employees. Journal Applied Psychology 91: 166175.

Dimitris, K. (2015). The Influence of Family on Adolescents' Use of Leisure. Multilingual Academic Journal of Education and Social Sciences, 3(1), 17-25.

Dysvik, A., Kuvaas, B., \& Buch, R. (2014). Perceived training intensity and work effort: The moderating role of perceived supervisor support. European Journal of Work and Organizational Psychology 23(5): 729-738.

Eckerd, S., Hill, J., Boyer, K. K., Donohue, K., \& Ward, P. T. (2013). The relative impact of attribute, severity, and timing of psychological contract breach on behavioral and attitudinal outcomes. Journal Operational Management 31, 567-578.

Eisenberger R, Armeli S, Rexwinkel B, Lynch P. D. \& Rhoades, L. (2001). Reciprocation of perceived organizational support. Journal of Applied Psychology 86: 42-51.

Eisenberger R, Stinglhamber F (2011). Perceived organizational support: fostering enthusiastic and productive employees. American Psychological Association Books, Washington.

Fornell, C., \& Larcker, D. F. (1981). Evaluating structural equation models with unobservable variables and measurement error. Journal of Marketing Research 18(1): 39-50.

Fox, S., \& Spector, P. E. (2002). Emotions in the workplace: The neglected side of organizational life introduction. Human Resource Management Review 12, 167-171.

Gilbert, J. A., \& Tang, T. L. (1998). An examination of Organizational trust antecedents. Public personnel Management Journal 27(1): 321-338.

Golparvar, M., Karami, M., \& Javadian, Z. (2012). Moderating effects of job stress in emotional exhaustion and feeling of energy relationships with positive and negative behaviors: Job 
INTERNATIONAL JOURNAL OF ACADEMIC RESEARCH IN BUSINESS AND SOCIAL SCIENCES

Vol. 10, No. 2, Feb, 2020, E-ISSN: 2222-6990 @ 2020 HRMARS

stress multiple functions approach. International Journal of Psychological Studies 4(4): 99122

Guchait, P., Cho, S., \& Meur, J. A. (2015). Psychological Contracts, Perceived Organizational and Supervisor Support: Investigating the Impact on Intent to Leave Among Hospitality Employees in India. Journal of Human Resources in Hospitality \& Tourism 14(3): 290-315.

Hair, J. F., Black, W., Babin, B., \& Anderson, R. (2010). Multivariate Data Analysis: A Global Perspective. Upper Saddle River, N.J.; London: Pearson Education.

Hakanen, J. J., Bakker, A. B., \& Schaufeli, W. B. (2006). Burnout and work engagement among teachers. Journal of School Psychology 43(6): 495-513.

Hanımoğlu, E. (2018). Deviant Behavior in School Setting. Journal of Education and Training Studies 6(10): 133-141.

Henseler, J., Ringle, C., \& Sarstedt, M. (2015). A new criterion for assessing discriminant validity in variance-based structural equation modeling. Journal of the Academy of Marketing Science 43(1): 115-135.

Huang, J., Wang, L., Shi, J. \& Xie, L. (2015). Leader-member exchange social comparison and employee deviant behavior: Evidence from a Chinese context. Social Behavior and Personality: An International Journal 43: 1273-1286.

Gold, A. H., Malhotra, A., \& Segars, A. H. (2001). Knowledge management: An organizational capabilities perspective. Journal of Management Information Systems 18(1): 185-214.

Jensen, J. M., \& Ryan, A. M. (2010). Psychological contracts and counterproductive work behaviors: employee responses to transactional and relational breach. Journal Business Psychology 25: 555-568.

Karabey, C. N., \& Yildirim, S. K. (2016). The mediating role of supervisor support in the relationship between individual differences and psychological contract breach. Journal of Business Research-Türk 8(1): 140-160.

Khan, S. I., Mahmood, A., Kanwal, S., \& Latif, Y. (2015). How Perceived Supervisor Support Effects Workplace Deviance? Mediating Role of Perceived Organizational Support. Pakistan Journal of Commerce and Social Sciences 9(3): 940-967.

Kickul, J. (2001). When organizations break their promises: employee reactions to unfair processes and treatment. Journal of Business Ethics 29: 289-307.

Law, K. S., \& Zhou, Y. (2014). On the relationship between implicit attitudes and counterproductive work behaviors. Asia Pacific Journal of Management 31: 643-659.

Li, S., \& Chen, Y. (2018). The Relationship Between Psychological Contract Breach and Employees' Counterproductive Work Behaviors: The Mediating Effect of Organizational Cynicism and Work Alienation. Frontiers Psychology 9, 1-13.

Liao, H., Joshi, A. \& Chuang, A. (2004). Sticking out like a sore thumb: employee dissimilarity and deviance at work. Journal of Personnel Psychology 57(4): 969-1000.

Liu, C-M., Huang, C-J., Huang, K-P., \& Chen, K-J. (2013). Psychological Contract Breach, Organizational Trust and Organizational Citizenship Behavior of Hotel Industry in Taiwan. Pakistan Journal of Statistics 29(5): 635-648.

Menguc, B., Auh, S., Fisher, M., \& Haddad, A. (2013). To be engaged or not to be engaged: The antecedents and consequences of service employee engagement. Journal of Business Research 66(11): 2163-2170. 
INTERNATIONAL JOURNAL OF ACADEMIC RESEARCH IN BUSINESS AND SOCIAL SCIENCES

Vol. 10, No. 2, Feb, 2020, E-ISSN: 2222-6990 @ 2020 HRMARS

Morrison, E. W., \& Robinson, S. L. (1997). When employees feel betrayed: A model of how psychological contract violation develops. Academy of Management Review 22, 226-256.

Mount, M., Ilies, R., \& Johnson, E. (2006). Relationship of personality traits and counterproductive work behaviors: the mediating effects of job satisfaction. Personal Psychology 59: 591-622.

Narayanan, K., \& Murphy, (2017). Conceptual framework on workplace deviance behavior: A Review. Journal of Human Values 23(4): 1-31.

Nunnally, J. C. \& Bernstein, I. H. (1994). Psychometric theory (3rd ed.). New York,: McGraw-Hill. Ozyilmaz, A. 2010. Vertical trust in organisation: a review of empirical studies over the last decade. Journal of Social Sciences Institute 7(13): 1-28.

Palomo, M., Beinart, H., \& Cooper, M. J. (2010). Development and validation of the Supervisory Relationship Questionnaire (SRQ) in UK trainee clinical psychologists. British Journal of Clinical Psychology 49: 131-149

Pandey, A., Schulz, E. R., \& Camp, R. R. (2018). The impact of supervisory support for highperformance human resource practices on employee in-role, extra-role and counterproductive behaviors. Journal of Managerial Issues 30(1): 97-121.

Penney, L. M., \& Spector, P. E. (2005). Job stress, incivility, and counterproductive work behavior (CWB): The moderation role of negative affectivity. Journal of Organizational Behavior 26, 777-796.

Peterson, D. K. (2002). Deviant workplace behavior and the organization's ethical climate. Journal of Business and Psychology 17(1): 47-61.

Reina, D. \& Reina, M. (1999). Trust and Betrayal in the workplace: Building effective relationship in your organization. Berrett-Koehler, San Francisco, CA.

Robinson, S. L. (1996). Trust and breach of the psychological contract. Administrative Science Quarterly 41(4): 574-599.

Robinson, S., \& Bennett, R. (1995). A typology of deviant workplace behaviors: A multi-dimensional scaling study. Academy of Management Journal 38, 555-572.

Robinson, S.L., \& Morrison, E.W. (2000). The development of psychological contract breach and violation: a longitudinal study. Journal of Organizational Behavior 21(5): 525-546.

Samadi, B., Wei, C., Seyfee, S. \&Yusoff, W. (2015).Conceptual model of organizational trust and knowledge sharing behavior among multi- generational employees. Asian Social Science 11(9): 32-42.

Sani, M. K. A., Daud, Z., \& Ismail, S. A. (2018). The form of psychological contract amongst employees at Department of Agricultural Malaysia based Agencies Malaysia. International Journal of Business and Social Science 9(1): 22-26.

Thau, S., \& Mitchell, M. S. (2010). Self-gain or self-regulation impairment? Tests of competing explanations of the supervisor abuse and employee deviance relationship through perceptions of distributive justice. Journal of Applied Psychology 95(6): 1009-1031.

Unal, A. (2012). Deviant teacher behaviors and their influence on school rules and interpersonal relationships at school. Egitim Arastirmalari - Eurasian Journal of Educational Research, 49, 1-20.

Wayne, S. J., Shore, L. M., Bommer, W. H. \& Tetrick, L. E. (2002). The role of fair treatment and rewards in perceptions of organisational support and leader-member exchange. Journal of Applied Psychology 87(3): 590-598. 
INTERNATIONAL JOURNAL OF ACADEMIC RESEARCH IN BUSINESS AND SOCIAL SCIENCES

Vol. 10, No. 2, Feb, 2020, E-ISSN: 2222-6990 @ 2020 HRMARS

Webster, J. \& Wong, W.K. (2008). Comparing traditional and virtual group forms: Identity, communication and trust in naturally occurring project teams. The International Journal of Human Resource Management 19(1): 41-62.

Yin, K. Y., Yusof, R., Lok, S. Y. P., \& Zakariya, Z. (2018). The Effects of Collaborative Mobile Learning Using Edmodo among Economics Undergraduates. International Journal of Academic Research in Progressive Education and Development, 7(3), 40-47.

Zulfadhli (2018). Determination of Industrial Competitiveness on Manufacturing Industry Growth in Palembang City, International Journal of Academic Research in Accounting, Finance and Management Sciences 8 (3): 238-254. 